\title{
Efficacy of LD Bio Aspergillus ICT Lateral flow assay for serodiagnosis of chronic pulmonary aspergillosis
}

Animesh Ray ${ }^{\mathrm{a}}$, Mohit Chowdhury ${ }^{\mathrm{a}}$, Janya Sachdev ${ }^{\mathrm{b}}$, Prayas Sethi ${ }^{\mathrm{a}}$, Ved Prakash Meena ${ }^{\mathrm{a}}$, Gagandeep Singh $^{\mathrm{b}}$, Immaculata Xess ${ }^{\mathrm{b}}$, Surabhi Vyas ${ }^{\mathrm{c}}$, MA Khan ${ }^{\mathrm{d}}$, Sanjeev Sinha ${ }^{\mathrm{a}}$, David W. Denning $^{\mathrm{f}}$, Naveet Wig ${ }^{\mathrm{a}}$, SK Kabra ${ }^{\mathrm{e}}$

${ }^{a}$ Department of Medicine, AlIMS, New Delhi.

${ }^{\mathrm{b}}$ Department of Microbiology, AlIMS, New Delhi

c Department of Radiodiagnosis, AlIMS, New Delhi

${ }^{\mathrm{d}}$ Department of Biostatistics, AllMS, New Delhi

e Department of Pediatrics, AlIMS, New Delhi

f Manchester Fungal Infection Group, University of Manchester, Manchester Academic Health Science Centre, Manchester, United Kingdom and Global Action Fund for Fungal Infections, Geneva, Switzerland. ORCID: 0000-0001-5626-2251

Corresponding author: Animesh Ray, Associate Professor, Department of Medicine, AllMS New Delhi. ORCID: 0000-0002-9434-5338

Keywords: chronic pulmonary aspergillosis, aspergillosis, LDBio LFA, IgG, Aspergillus, posttuberculosis, fungus, lateral flow assay, serodiagnosis, CPA

\section{Abstract :}

Background: The diagnosis of CPA relies on the detection of IgG Aspergillus antibody which is not freely available, especially in resource-poor settings. Point-of-care tests like LDBio Aspergillus ICT lateral flow assay, evaluated in only a few studies, have shown promising results for diagnosis of CPA. However no study has compared the diagnostic performances of LDBio LFA in setting of tuberculosis endemic countries and have compared it with that of IgG Aspergillus.

Objectives: This study aimed to evaluate the diagnostic performances of LDBio LFA in CPA and compare it with existing diagnostic algorithm utilising ImmunoCAP IgG Aspergillus.

Methods: Serial patients presenting with respiratory symptoms (cough, hemoptysis, fever etc) for $>4$ weeks were screened for eligibility. Relevant investigations including direct microscopy and culture of respiratory secretions, IgG Aspergillus, chest imaging etc were done according to existing algorithm. Serum of all patients were tested by LDBio LFA and IgG Aspergillus (ImmunoCAP Asp IgG) and their diagnostic performances were compared.

Results: A total of 174 patients were included in the study with $~ 66.7 \%$ patients having past history of tuberculosis. A diagnosis of CPA was made in 74 (42.5\%) of patients. The estimated sensitivity and specificity of LDBio LFA was $67.6 \%$ (95\% Cl: $55.7 \%-78 \%$ ) and $81 \%$ (95\% Cl: $71.9 \%-81 \%$ ) respectively which increased to $73.3 \%$ (95\% Cl: $60.3 \%-83.9 \%)$ and $83.9 \%$ (95\% Cl: $71.7 \%-92.4 \%)$ respectively in patients with past history of tuberculosis. The sensitivity and specificity of IgG Aspergillus was $82.4 \%$ (95\% Cl: $71.8 \%-90.3 \%)$ and 82\% (95\% Cl: 73.1-89\%); 86.7\% (95\% Cl: 75.4\%-94.1\%) and $80.4 \%$ (95\% Cl: $67.6 \%-89.8 \%$ ) in the whole group and those with past history of tuberculosis respectively.

Conclusions: LDBio LFA is a point-of-care test with reasonable sensitivity and specificity. However, further tests may have to be done to rule-in or rule-out the diagnosis of CPA in the appropriate

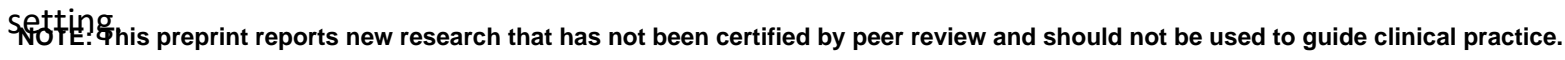


medRxiv preprint doi: https://doi.org/10.1101/2022.03.04.22271825; this version posted March 7, 2022. The copyright holder for this preprint (which was not certified by peer review) is the author/funder, who has granted medRxiv a license to display the preprint in perpetuity.

All rights reserved. No reuse allowed without permission.

\section{$\underline{\text { Introduction }}$}

The relationship between the fungus and the host typically determines the manifestation of Aspergillus lung disease ranging from acute and subacute invasive to chronic pulmonary aspergillosis. ${ }^{1},{ }^{2}$ Chronic pulmonary aspergillosis (CPA) is a collection of serious illnesses characterised by persistent cough, dyspnea, haemoptysis, fatigue and weight loss. ${ }^{3}$ Chronic cavitary pulmonary aspergillosis (CCPA) is the most frequent manifestation of CPA, which can progress to chronic fibrosing pulmonary aspergillosis if left untreated. Single aspergilloma and Aspergillus nodule are some of the less prevalent manifestations of CPA. ${ }^{4}$ Pre-disposing factors for CPA include underlying pulmonary illnesses like chronic obstructive pulmonary disease (COPD) or mycobacteriosis, as well as prevalent immunosuppressive disorders like diabetes. ${ }^{3}$

Patients with CPA have significant morbidity affecting roughly 3 million individuals globally. The overall 5-year mortality rate ranges up to $80 \%$, resulting in an estimated 450,000 yearly fatalities. ${ }^{5}$ As a result of India's high TB disease load, post-tuberculosis sequelae are common. ${ }^{6}$ CPA has an annual incidence of 27,000 to 170,000 cases, with a 5 -year prevalence of 24 per $100,000 .^{7}$ In India, the prevalence may be very high in post-tuberculosis sequelae patients ( $\sim 57 \%$ ) and recurrence of tuberculosis has been reported to be an important independent risk factor for development of CPA. ${ }^{8}$ No single clinical or radiological manifestation or laboratory result is adequate for a conclusive diagnosis of CPA; rather, an amalgamation of clinical, radiographic, and microbiological findings is used since the presentation may be non-specific and might be difficult to differentiate from pulmonary tuberculosis. ${ }^{9}, 10,11,12$ The microbiological evidence for diagnosis is considered with direct confirmation of Aspergillus infection (microscopy or culture from BAL fluid/biopsy) or a immune response to Aspergillus spp. ${ }^{4}$

In the frequent absence of positive cultures, serologic assays are essential for diagnosis of CPA. ${ }^{13}$ In the earliest assay formats, antibodies against Aspergillus fumigatus were identified by detection of precipitins with high specificity utilising the double immunodiffusion test (DID) or counter immune-electrophoresis (CIE) technique. These methods however had a long turnaround time, required significant labour with a large inoculum of fungal extract and patient serum extracts, and the results were only semi-quantitative. ${ }^{13}$ Other commercially accessible serological tests subsequently were launched which may be employed for diagnosis of CPA, such as enzyme immunoassay (EIA), enzyme-linked immunosorbent assay (ELISA) and indirect hemagglutination (IHA), however performance levels vary amongst tests, and redefining of cut-off values for different populations and diagnoses may be required to maximise performance. ${ }^{9}$ Indirect hemagglutination is clearly inferior to other methods. ${ }^{14}{ }^{14}$ Moreover, performance of these tests often requires costly equipment, steady power supply, technical expertise as well as considerable costs.

In recent years, the lateral flow assay (LFA) has been employed to simplify Aspergillus IgG detection with quick turn-around time and little laboratory equipment. The only commercially available LFA for detecting Aspergillus IgG is LDBio LFA Aspergillus immunochromatographic technology (hereafter referred to as LDBio LFA). ${ }^{15} \mathrm{~A}$ point-of-care test has been felt to be essential in simplifying the diagnosis and management of CPA, especially in a resource-limited setting. When compared to ImmunoCAP (Thermo Fisher) for levels of Aspergillus fumigatus specific IgG (hereafter referred to as ImmunoCAP Asp IgG), the LDBio LFA has exhibited good sensitivity and specificity for detection of CPA in studies done in centres in France and United Kingdom. ${ }^{16},{ }^{17}$ A study had also reported sensitivity and specificity of $80 \%$ and $70 \%$ respectively of LDBio LFA from Indonesia, which however did not use an alternative IgG Aspergillus in the diagnostic algorithm. So, the present study was conducted out of the necessity of evaluating the diagnostic performances of this point-of-care 
medRxiv preprint doi: https://doi.org/10.1101/2022.03.04.22271825; this version posted March 7, 2022. The copyright holder for this preprint (which was not certified by peer review) is the author/funder, who has granted medRxiv a license to display the preprint in perpetuity.

All rights reserved. No reuse allowed without permission.

test in a tuberculosis endemic country with a significant burden of CPA and to compare it with the existing diagnostic criteria including IgG Aspergillus.

\section{Materials \& Methods}

Between February 2020 and December 2021, consecutive patients presenting to chest clinic of a tertiary care unit in North India with respiratory symptoms (cough, hemoptysis, fever, shortness of breath, chest pain etc) of more than four weeks duration were enrolled in the study. Patients with an apparent non-CPA diagnosis such as lung malignancy or who refused consent for serological tests were excluded from the study. Ethical permission was taken from Institute Ethics Committee for the conduct of this study (IEC-52/08.01.2021, RP-10/2021). Written consent form was obtained from all participants before enrolment into the study as per institutional protocol.

After enrolment, the case details were recorded in a standardized case record form (CRF), by a trained professional. Relevant investigations including blood tests, chest imaging, sputum examination, bronchoalveolar lavage was done as per the discretion of the treating physician. Serum samples collected from all the individuals were evaluated by LDBio LFA assays and ImmunoCAP Asp IgG assay. The diagnosis of CPA was made individually by two researchers (AR and $\mathrm{MC}$ ), and then corroborated as per the European Respiratory Society/European Society of Clinical Microbiology and Infectious Diseases (ERS/ESCMID) criteria. ${ }^{18}$ The diagnosis relied on appropriate clinical, radiological and microbiological parameters. Microbiological evidence included a positive serological result using the ImmunoCAP Asp IgG assay to measure Aspergillus-specific IgG levels (> 27 mgA milligrams of antibodies]/liter considered to be the cut-off for positive result), histopathological evidence of CPA following lung biopsy or resection, positive result in galactomannan assay performed on serum or BAL samples using the Platelia Aspergillus galactomannan ELISA (Bio-Rad Laboratories) interpreted according to cutoffs provided in the 2019 EORTC/MSGERC guidelines (galactomannan index $>1$ was considered positive for both serum and BAL), and respiratory samples showing hyaline septate hyphae morphologically suggestive of Aspergillus spp in direct microscopy, or growth of Aspergillus spp in culture ${ }^{4}$. Radiological criteria for diagnosis were adapted from those used commonly in a resource-constrained setting ${ }^{19}$ The Aspergillus ICT IgG IgM lateral flow assay (LDBio LFA, Diagnostics, Lyon, France) was used to test each sample, and all tests were performed and interpreted according to the manufacturer's instructions. The presence of a well-defined black line at the "Test (T)" and "Control (C)" markers was considered as a positive result. The presence of a thin, diffuse grey line at the " $T$ " marker indicates a "weakly positive" result. .

An alternative analyses was done assuming cut-off of $40 \mathrm{mgA} / \mathrm{L}$ for IgG against Aspergillus spp, as is suggested by the manufacturer as well as validated in studies. ${ }^{17} 2021$

\section{$\underline{\text { Statistical analysis }}$}

The sample size was estimated considering a sensitivity of $85 \%$ and specificity of $84 \%$ (average of the diagnostic accuracies reported by Hunter et al ${ }^{17}$ in healthy population and Rozaliyani et al $^{22}$ in tuberculosis-treated patients) and taking a precision of $8.5 \%$ with $95 \%$ confidence level. The sample size estimated was at least 68 cases and 72 non-CPA cases.

Categorical and continuous variables were reported in frequencies and in percentages and mean with standard deviation/median with minimum, maximum depending on the nature of the data respectively. Fisher's exact /chi-squared tests were used to establish association for categorical variables while Student's t-test or Wilcoxon ranksum test was used for continuous variables as appropriate. Those with $p$ value $<0.05$ were considered to be significant. 
medRxiv preprint doi: https://doi.org/10.1101/2022.03.04.22271825; this version posted March 7, 2022. The copyright holder for this preprint (which was not certified by peer review) is the author/funder, who has granted medRxiv a license to display the preprint in perpetuity.

All rights reserved. No reuse allowed without permission.

\section{$\underline{\text { Results }}$}

A total of 218 patients were screened and 174 patients were included in this study (figure 1). The baseline characteristics of the study population are detailed in Tables 1-3. One hundred and sixteen $(62.1 \%)$ enrollees were male with a mean age of 40.7 ( \pm 13.9 years). The vast majority of patients (98.3\%) were HIV seronegative. In total, 116 (66.67\%) patients had a prior history of documented pulmonary tuberculosis and $46(29.1 \%)$ had used inhalational devices in the last month.

In this study population, 74 patients (42.5\%) fulfilled the diagnosis of CPA while a diagnosis of allergic bronchopulmonary aspergillosis was made in $13(7.5 \%)$ patients. Out of the 74 patients with CPA 44 (60.3\%) had chronic cavitary pulmonary aspergillosis, 19 (26\%) chronic fibrosing pulmonary aspergillosis and 10 (13.7\%) had Aspergillus nodules. Majority of the patients(> 90\%) was diagnosed by positive ImmunoCAP Asp IgG assay as the sole microbiological criteria along with corroborative clinic-radiological features. Pulmonary tuberculosis was diagnosed in 16 (9.2\%) patients. Cough was the most common symptom, reported in 106 (61.6\%) patients. On chest imaging, cavity was the most common reported finding, being present in 74 patients (42.5\%). Serum IgG specific for Aspergillus fumigatus was elevated in 61 (82.4\%) of the group diagnosed with CPA. Out of 131 patients who produced sputum or underwent bronchoalveolar lavage (BAL), fungal culture showed growth of Aspergillus spp in nine patients (6.9\%). BAL galactomannan was positive in 17 (9.8\%) patients in those with CPA.

The sensitivity and specificity of LDBio LFA for diagnosis of CPA (as compared to the ERS/ESCMID criteria) in our study subjects presenting with respiratory symptoms for at least four weeks was $67.6 \%$ (95\% Cl: 55.7\%- 78\%)_and 81\%_(95\% Cl: 71.9\%-81\%) respectively with a diagnostic accuracy of $75.3 \%$. In the population with a past history of tuberculosis, the sensitivity and specificity improved to $73.3 \%$ (95\% Cl: $60.3 \%-83.9 \%$ ) and $83.9 \%$ (95\% Cl: $71.7 \%-92.4 \%$ ) respectively; and the estimated diagnostic accuracy was $78.5 \%$. In those with past history of tuberculosis and with symptoms $>3$ months, the sensitivity and specificity further improved to $74.1 \%$ (95\% Cl: $60.3 \%-85 \%)$ and $85 \%$ (95\% Cl: $70.2 \%-94.3 \%)$ respectively; with diagnostic accuracy being $78.7 \%$.

In contrast, the sensitivity and specificity for ImmunoCAP Asp IgG for diagnosis of CPA was $82.4 \%$ (95\% Cl: $71.8 \%-90.3 \%)$ and $82 \%$ (95\% Cl: $73.1-89 \%)$ respectively. The diagnostic performances of both LDBio LFA and IgG are represented in Table 4. The kappa for agreement between LDBio LFA and Aspergillus fumigatus was 0.53 .

According to the alternative analyses using cut-off of Aspergillus-specific IgG assay as $40 \mathrm{mgA} / \mathrm{L}$, the diagnostic performances of LDBio LFA were altered (in most cases the diagnostic accuracies marginally fell) as shown in Table 5 . Chest radiograph and CT thorax of a CPA patient who was negative for both ImmunoCAP Asp IgG \& LDBio LFA is depicted in figure 3

\section{Discussion}

The benefits of LDBio LFA under evaluation reported in existing literature include minimal requirement of resources, time and machinery - all of which are important in diagnosing CPA in resource-constrained settings where CPA is predominantly found. In the present study, in a population presenting with symptoms predominantly suggestive of persistent respiratory symptoms ( $>$ four weeks), the assay had a sensitivity, specificity and diagnostic accuracy of $67.6 \%, 81 \%$ and $75.3 \%$ respectively. In the population who had a past history of pulmonary tuberculosis, the 
medRxiv preprint doi: https://doi.org/10.1101/2022.03.04.22271825; this version posted March 7, 2022. The copyright holder for this preprint (which was not certified by peer review) is the author/funder, who has granted medRxiv a license to display the preprint in perpetuity.

All rights reserved. No reuse allowed without permission.

sensitivity, specificity and diagnostic accuracy of the assay increased to $73.3 \%, 83.9 \%$ and $78.5 \%$ respectively. The ImmunoCAP Asp IgG assay for detection of IgG Aspergillus fumigatus in the same population had a better sensitivity of $\sim 82.4 \%$ and diagnostic accuracy of $82.2 \%$ though with similar specificity (82\%), using a cutoff of $>27 \mathrm{~mA} / \mathrm{ml}$. This performance is not as good as published previously at the same cutoff from a previous study. ${ }^{23}$ The possible reason may be the inclusion of serum galactomannan (EIA> 0.5) as microbiological criteria for diagnosis of CPA in the previous study. A significant proportion of controls in our study was also positive for serum galactomannan indicating a plausibility of false positivity owing to previous antibiotics or food habits. ${ }^{24}{ }^{25}$ There was moderate degree of agreement ${ }^{26}$ between LDBio LFA and the ImmunoCAP Asp IgG assay (kappa=0.53).

Diagnosis of CPA is dependent on the use of serological tests especially lgG against Aspergillus $s p p$ in addition to radiological features ${ }^{18}$. Since the antibody estimation is costly, access to these tests are often restricted in resource constrained settings. ${ }^{27}$ On the other hand, conventional fungal cultures have typically poor positivity rate (ranging from $10-40 \%$ ) ${ }^{28}$ which might increase markedly by high volume culture ( 54\% in mixed cases of pulmonary aspergillosis) $)^{29}$. Further, different features on chest radiographs and CT scans have variable sensitivity and specificity which may be as low as $\sim 28 \%{ }^{30}$ For example, a normal chest radiograph had an excellent performance in ruling out $\mathrm{CPA}$, and such patients do not need testing for Aspergillus IgG. ${ }^{30}$ Utility of galactomannan antigen in serum or BAL have been evaluated in numerous studies which have yielded different cut-offs, making it difficult to introduce a uniform criteria for diagnosis of CPA. ${ }^{31}{ }^{32}{ }^{33}$ Access to point-of-care tests like LDBio LFA, is important in identifying the significant load of CPA patients in tuberculosisendemic countries which are usually 'economically developing' and resource constrained. Our study shows that this assay can be used as a screening test to detect $70 \%$ of CPA patients. However, the test may be false-negative in $30 \%$ of CPA patients, implying that other ancillary tests have to be performed before ruling out the diagnosis of CPA in those patients with high index of suspicion. Our study also showed that LDBio LFA and ImmunoCAP Asp IgG assay had similar specificity 82\% suggesting that the former may be a reliable 'rule-in' test. In the light of the present study, it seems that LDBio LFA, though demonstrating lower sensitivity and comparable specificity IgG Aspergillus, may have a significant role in identifying patients with CPA. It can be used a screening test in patients presenting with persistent respiratory symptoms in whom CPA is a probable diagnosis. Due to the low sensitivity of LDBio LFA, those who are negative, need to be followed up with other tests like IgG against Aspergillus. Those who are positive, may be treated as cases of CPA, owing to similar specificity of ImmunoCAP Asp IgG assay, provided the clinical and radiological features are compatible with the diagnosis of CPA. An algorithm depicting the possible role of LDBio LFA is depicted in Figure 2.

The effectiveness of the LDBio LFA in diagnosing CPA has been demonstrated in three previous studies - one each in France, United Kingdom and Indonesia and its use has also been reported from a case study from Uganda. ${ }^{34}$ The reported sensitivity and specificity in the three studies along with that of our study is shown in table 6 . The differences in the sensitivities/specificities of the three studies can be explained by the difference in the recruited population. While, the Indonesian study included patients after completion of tuberculosis therapy, the UK study included sera of known CPA patients and used 'matched' sera of healthy controls. In our study, we recruited patients from outpatients and inpatient settings with predominantly chronic respiratory symptoms as the primary presenting complaint. Different diagnostic criteria were used in the various studies. Approximately $66.7 \%$ of our patients had past history of pulmonary tuberculosis. Our study population likely 
medRxiv preprint doi: https://doi.org/10.1101/2022.03.04.22271825; this version posted March 7, 2022. The copyright holder for this preprint (which was not certified by peer review) is the author/funder, who has granted medRxiv a license to display the preprint in perpetuity.

All rights reserved. No reuse allowed without permission.

represented the real-life scenario where in CPA suspects often present without a past history of respiratory illnesses and often are misdiagnosed as 'smear-negative' tuberculosis. ${ }^{35}$ Our study had the following limitations. Only three patients of our patients $(<2 \%)$ were afflicted by HIV. The absolute number of patients with growth of Aspergillus spp in their respiratory samples was also lower ( 5.2\%) in our study population. However, in our study, all the diagnoses were confirmed using the existing guidelines for diagnosis of CPA and ImmunoCAP Asp IgG, which is widely regarded as a high quality quantitive diagnositic test, was performed in all patients.

Conclusion: LDBio LFA has reasonable sensitivity and specificity for diagnosis of CPA and can be used in resource-poor settings due to its simplicity of process, minimal requirement for equipment and infrastructure, quick turn-around time and low cost.

\section{$\underline{\text { References }}$}

1. Kosmidis C, Denning DW. The clinical spectrum of pulmonary aspergillosis. Thorax. 2015;70(3):270-277. doi:10.1136/thoraxjnl-2014-206291

2. Swain S, Ray A, Sarda R, et al. COVID-19-associated subacute invasive pulmonary aspergillosis. Mycoses. 2022;65(1):57-64. doi:10.1111/myc.13369

3. Schweer KE, Bangard C, Hekmat K, Cornely OA. Chronic pulmonary aspergillosis. Mycoses. 2014;57(5):257-270. doi:10.1111/myc.12152

4. Denning DW, Cadranel J, Beigelman-Aubry C, et al. Chronic pulmonary aspergillosis: rationale and clinical guidelines for diagnosis and management. Eur Respir J. 2016;47(1):45-68. doi:10.1183/13993003.00583-2015

5. Laursen CB, Davidsen JR, Van Acker L, et al. CPAnet Registry-An International Chronic Pulmonary Aspergillosis Registry. J Fungi. 2020;6(3):96. doi:10.3390/jof6030096

6. 2021.10.04.21264524v1.full.pdf. Accessed February 15, 2022. https://www.medrxiv.org/content/10.1101/2021.10.04.21264524v1.full.pdf

7. Agarwal R, Denning DW, Chakrabarti A. Estimation of the Burden of Chronic and Allergic Pulmonary Aspergillosis in India. Kirk M, ed. PLoS ONE. 2014;9(12):e114745. doi:10.1371/journal.pone.0114745

8. Singla R, Singhal R, Rathore R, et al. Risk factors for chronic pulmonary aspergillosis in postTB patients. Int J Tuberc Lung Dis Off J Int Union Tuberc Lung Dis. 2021;25(4):324-326. doi:10.5588/ijtld.20.0735

9. Stucky Hunter E, Richardson MD, Denning DW. Evaluation of LDBio Aspergillus ICT Lateral Flow Assay for IgG and IgM Antibody Detection in Chronic Pulmonary Aspergillosis. Land GA, ed. J Clin Microbiol. 2019;57(9). doi:10.1128/JCM.00538-19

10. Unusual case of chronic cavitary pulmonary aspergillosis presenting as spontaneous pneumothorax in an immunocompromised man | BMJ Case Reports. Accessed February 15, 2022. https://casereports.bmj.com/content/14/8/e241655

11. Sarda R, Ray A. TB and chronic pulmonary aspergillosis: a few relevant points. Int J Tuberc Lung Dis Off J Int Union Tuberc Lung Dis. 2021;25(11):959a-9959. doi:10.5588/ijtld.21.0415

12. Ragesh R, Ray A, Mian A, Vyas S, Sharma SK. Cavitary Lung Lesions in a Difficult-To-Treat Asthma Patient. J Assoc Physicians India. 2016;64(4):73-76. 
medRxiv preprint doi: https://doi.org/10.1101/2022.03.04.22271825; this version posted March 7, 2022. The copyright holder for this preprint (which was not certified by peer review) is the author/funder, who has granted medRxiv a license to display the preprint in perpetuity.

All rights reserved. No reuse allowed without permission.

13. Volpe Chaves CE, do Valle Leone de Oliveira SM, Venturini J, et al. Accuracy of serological tests for diagnosis of chronic pulmonary aspergillosis: A systematic review and meta-analysis. Agarwal R, ed. PLOS ONE. 2020;15(3):e0222738. doi:10.1371/journal.pone.0222738

14. Richardson MD, Page ID. Aspergillus serology: Have we arrived yet? Med Mycol. 2017;55(1):48-55. doi:10.1093/mmy/myw116

15. Rozaliyani A, Rosianawati H, Handayani D, et al. Chronic Pulmonary Aspergillosis in Post Tuberculosis Patients in Indonesia and the Role of LDBio Aspergillus ICT as Part of the Diagnosis Scheme. J Fungi. 2020;6(4):318. doi:10.3390/jof6040318

16. Piarroux RP, Romain $\mathrm{T}$, Martin A, et al. Multicenter Evaluation of a Novel Immunochromatographic Test for Anti-aspergillus IgG Detection. Front Cell Infect Microbiol. 2019;9:12. doi:10.3389/fcimb.2019.00012

17. Stucky Hunter E, Richardson MD, Denning DW. Evaluation of LDBio Aspergillus ICT Lateral Flow Assay for IgG and IgM Antibody Detection in Chronic Pulmonary Aspergillosis. J Clin Microbiol. 2019;57(9). doi:10.1128/JCM.00538-19

18. Denning DW, Cadranel J, Beigelman-Aubry C, et al. Chronic pulmonary aspergillosis: rationale and clinical guidelines for diagnosis and management. Eur Respir J. 2016;47(1):45-68. doi:10.1183/13993003.00583-2015

19. Denning DW, Page ID, Chakaya J, et al. Case Definition of Chronic Pulmonary Aspergillosis in Resource-Constrained Settings. Emerg Infect Dis. 2018;24(8). doi:10.3201/eid2408.171312

20. Page ID, Richardson MD, Denning DW. Comparison of six Aspergillus-specific IgG assays for the diagnosis of chronic pulmonary aspergillosis (CPA). J Infect. 2016;72(2):240-249. doi:10.1016/j.jinf.2015.11.003

21. Lee MR, Huang HL, Keng LT, et al. Establishing Aspergillus-Specific IgG Cut-Off Level for Chronic Pulmonary Aspergillosis Diagnosis: Multicenter Prospective Cohort Study. I Fungi. 2021;7(6):480. doi:10.3390/jof7060480

22. Rozaliyani A, Setianingrum F, Azahra S, et al. Performance of LDBio Aspergillus WB and ICT Antibody Detection in Chronic Pulmonary Aspergillosis. J Fungi Basel Switz. 2021;7(4):311. doi:10.3390/jof7040311

23. Sehgal IS, Choudhary H, Dhooria S, et al. Diagnostic cut-off of Aspergillus fumigatus-specific IgG in the diagnosis of chronic pulmonary aspergillosis. Mycoses. 2018;61(10):770-776. doi:10.1111/myc.12815

24. Hung $\mathrm{YH}$, Lai HH, Lin HC, Sun KS, Chen CY. Investigating Factors of False-Positive Results of Aspergillus Galactomannan Assay: A Case-Control Study in Intensive Care Units. Front Pharmacol. 2021;12:747280. doi:10.3389/fphar.2021.747280

25. Ng TY, Kang ML, Tan BH, Ngan CCL. Case report: Enteral nutritional supplement as a likely cause of false-positive galactomannan testing. Med Mycol Case Rep. 2014;3:11-13. doi:10.1016/j.mmcr.2013.11.004

26. Watson PF, Petrie A. Method agreement analysis: a review of correct methodology. Theriogenology. 2010;73(9):1167-1179. doi:10.1016/j.theriogenology.2010.01.003 
medRxiv preprint doi: https://doi.org/10.1101/2022.03.04.22271825; this version posted March 7, 2022. The copyright holder for this preprint (which was not certified by peer review) is the author/funder, who has granted medRxiv a license to display the preprint in perpetuity.

All rights reserved. No reuse allowed without permission.

27. Denning DW, Page ID, Chakaya J, et al. Case Definition of Chronic Pulmonary Aspergillosis in Resource-Constrained Settings. Emerg Infect Dis. 2018;24(8). doi:10.3201/eid2408.171312

28. Camuset J, Nunes $\mathrm{H}$, Dombret MC, et al. Treatment of chronic pulmonary aspergillosis by voriconazole in nonimmunocompromised patients. Chest. 2007;131(5):1435-1441. doi:10.1378/chest.06-2441

29. Vergidis $\mathrm{P}, \mathrm{Moore} \mathrm{CB}$, Novak-Frazer $\mathrm{L}$, et al. High-volume culture and quantitative real-time PCR for the detection of Aspergillus in sputum. Clin Microbiol Infect Off Publ Eur Soc Clin Microbiol Infect Dis. 2020;26(7):935-940. doi:10.1016/j.cmi.2019.11.019

30. Page ID, Byanyima R, Hosmane S, et al. Chronic pulmonary aspergillosis commonly complicates treated pulmonary tuberculosis with residual cavitation. Eur Respir J. 2019;53(3):1801184. doi:10.1183/13993003.01184-2018

31. Sehgal IS, Dhooria S, Choudhary $\mathrm{H}$, et al. Utility of Serum and Bronchoalveolar Lavage Fluid Galactomannan in Diagnosis of Chronic Pulmonary Aspergillosis. J Clin Microbiol. 2019;57(3):e0182118. doi:10.1128/JCM.01821-18

32. Shin $B$, Koh $W J$, Jeong $B H$, et al. Serum galactomannan antigen test for the diagnosis of chronic pulmonary aspergillosis. J Infect. 2014;68(5):494-499. doi:10.1016/j.jinf.2014.01.005

33. Izumikawa K, Yamamoto $\mathrm{Y}$, Mihara $\mathrm{T}$, et al. Bronchoalveolar lavage galactomannan for the diagnosis of chronic pulmonary aspergillosis. Med Mycol. 2012;50(8):811-817. doi:10.3109/13693786.2012.682228

34. Kwizera $\mathrm{R}$, Katende $\mathrm{A}$, Teu $\mathrm{A}$, et al. Algorithm-aided diagnosis of chronic pulmonary aspergillosis in low- and middle-income countries by use of a lateral flow device. Eur J Clin Microbiol Infect Dis Off Publ Eur Soc Clin Microbiol. 2020;39(1):1-3. doi:10.1007/s10096-019-03782-x

35. Oladele RO, Irurhe NK, Foden P, et al. Chronic pulmonary aspergillosis as a cause of smearnegative TB and/or TB treatment failure in Nigerians. Int J Tuberc Lung Dis Off J Int Union Tuberc Lung Dis. 2017;21(9):1056-1061. doi:10.5588/ijtld.17.0060 


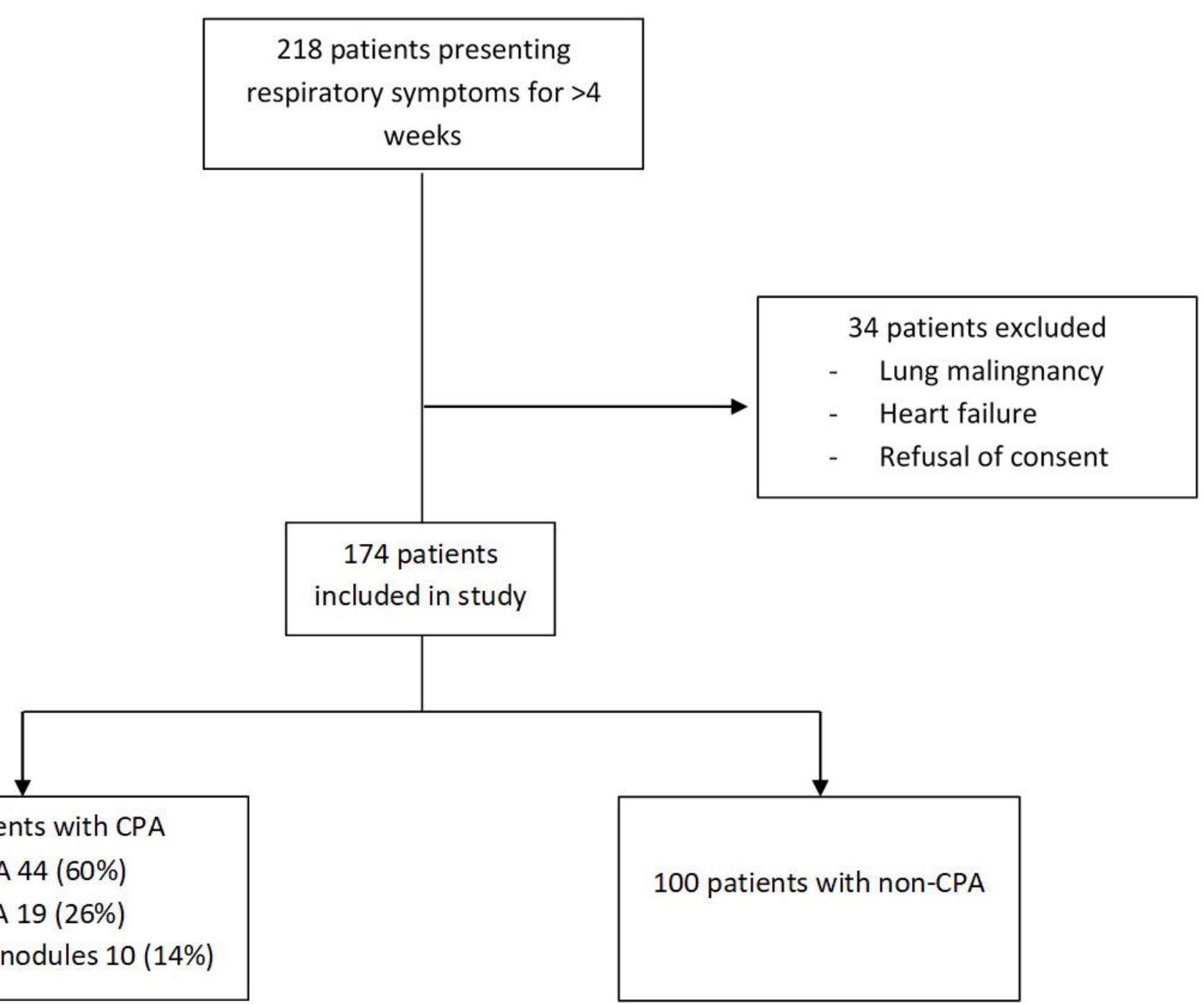




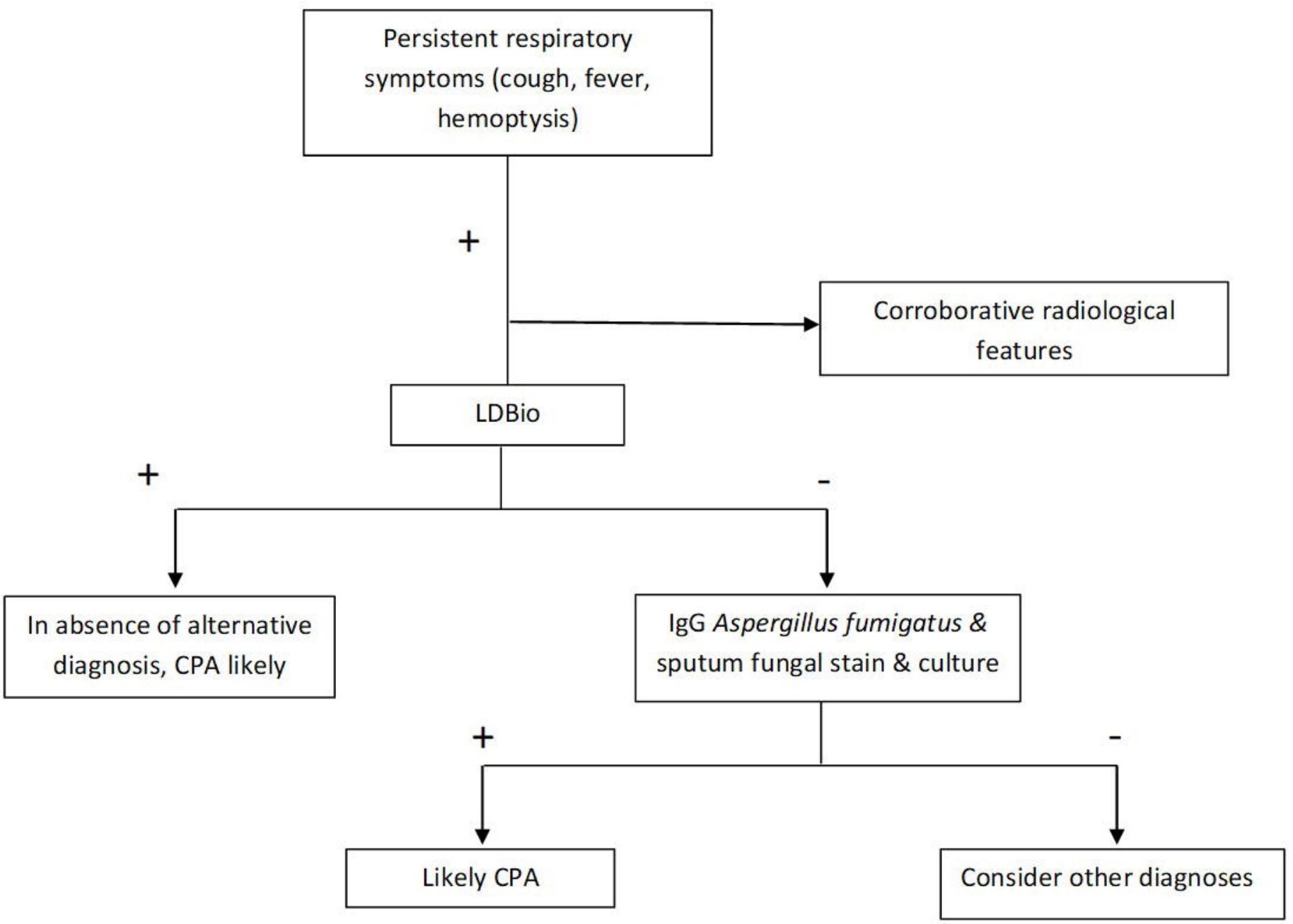




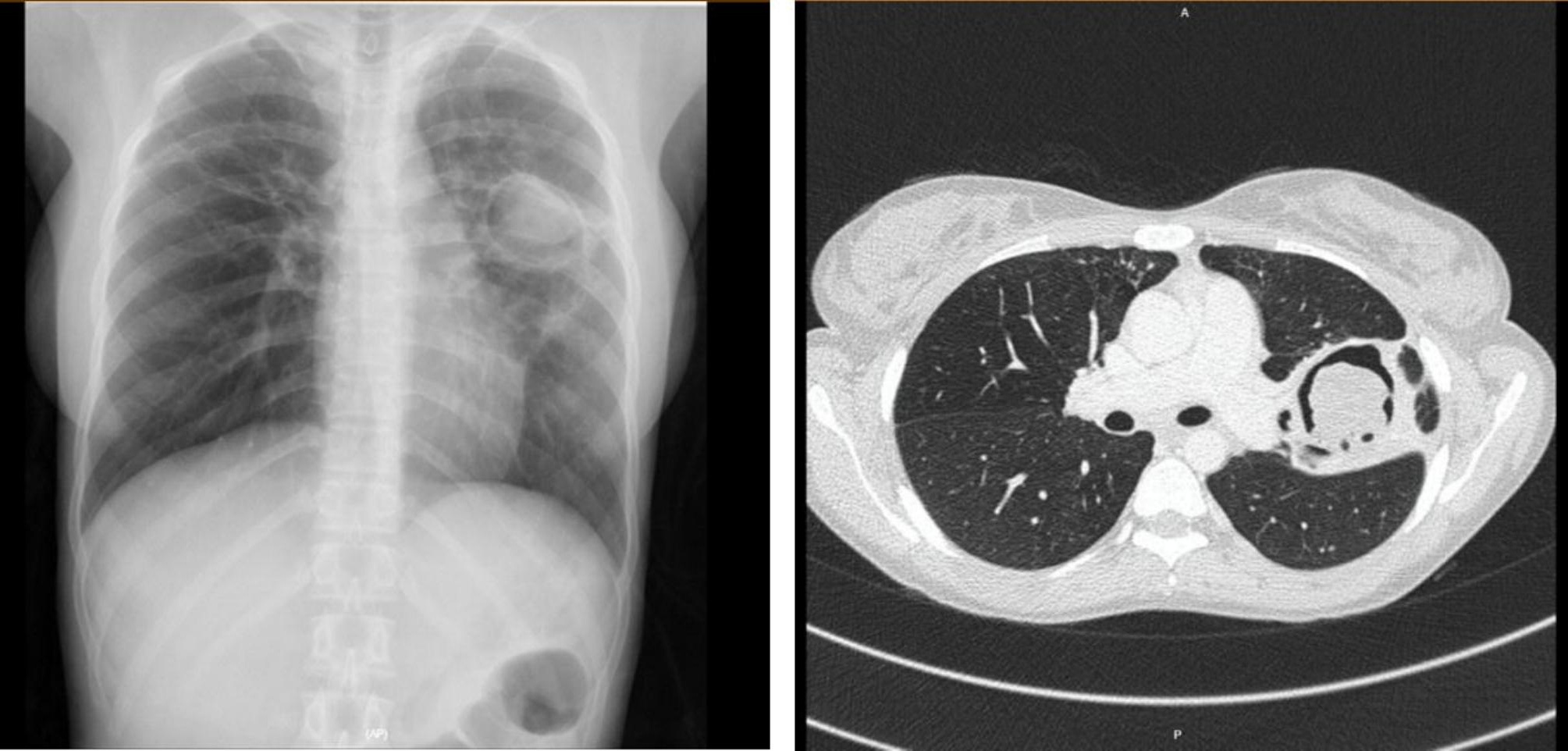




\begin{tabular}{|c|c|c|c|c|}
\hline \multicolumn{2}{|c|}{ Variables } & $\begin{array}{l}\text { Non-CPA } \\
(n=100)\end{array}$ & $\mathrm{CPA}(\mathrm{n}=74)$ & \\
\hline \multicolumn{2}{|c|}{ Age $( \pm S D)$} & $41.4( \pm 14.57)$ & $39.68( \pm 13.05)$ & 0.42 \\
\hline \multirow[t]{2}{*}{ Sex } & Male & $66(66.0 \%)$ & $42(56.8 \%)$ & \multirow[t]{2}{*}{0.21} \\
\hline & Female & 34 (34.0\%) & $32(43.2 \%)$ & \\
\hline
\end{tabular}

PAST HISTORY

\begin{tabular}{|l|lll|}
\hline Tuberculosis & $\mathbf{5 6 ( 5 6 . 0 \% )}$ & $60(81.1 \%)$ & 0.001 \\
\hline HIV & $2(2.0 \%)$ & $1(1.35 \%)$ & $>0.99$ \\
\hline ABPA & $12(12.0 \%)$ & $1(1.35 \%)$ & $(0.008)$ \\
\hline MDI use & $28(30.4 \%)$ & $18(27.3 \%)$ & 0.67
\end{tabular}

\begin{tabular}{|}
\hline \\
\hline \\
\hline
\end{tabular}

\begin{tabular}{|l|lll}
\hline Fever & $10(10.2 \%)$ & $13(17.6 \%)$ & $(0.16)$ \\
\hline Cough & $53(54.1 \%)$ & $53(71.6 \%)$ & 0.02 \\
\hline Weight loss & $25(25.5 \%)$ & $25(33.8 \%)$ & 0.24 \\
\hline Breathlessness & $46(46.9 \%)$ & $31(41.9 \%)$ & 0.51 \\
\hline Haemoptysis & $17(17.4 \%)$ & $34(46 \%)$ & $<0.001$ \\
\hline Fatigue & $0(0 \%)$ & $2(100 \%)$ & 0.33 \\
\hline Any symptom & $84(84.0 \%)$ & $68(91.9 \%)$ & 0.12 \\
\hline No.(\%) with Post-TB sequelae & $29(29 \%)$ & $52(70.3 \%)$ & \\
\hline $\begin{array}{l}\text { No.(\%) with } \\
\text { pulmonary/disseminated TB }\end{array}$ & $21(21 \%)$ & $9(12.2 \%)$ &
\end{tabular}

\section{No}

$\mathrm{No}$

dis

\begin{tabular}{ll}
$\mathrm{d}$ \\
\hline $\mathrm{No}$ \\
\hline $\mathrm{No}$ \\
\hline
\end{tabular}

No.(\%) with $\mathrm{ABPA}$

No.(\%) with obstructive airway

$11(11 \%)$

$1(1.4 \%)$

$13(13 \%)$

$2(2.7 \%)$

disease

No.(\%) with sarcoidosis

No.(\%) with ILD

$5(5 \%)$

$0(0 \%)$

$1(1 \%)$

$1(1.4 \%)$

No.(\%) with others

- Lung

malignancy/metastasis

- Lung mass under evaluation

- Pulmonary / disseminated cryptococcosis

- Pulmonary/ disseminated mucormycosis

- Post COVID sequelae

- Gujjar's lung

- Chronic hypersensitivity pneumonitis

- PUO

- Bronchiectasis under evaluation

$\begin{array}{ll}4(4 \%) & 0(0 \%) \\ 4(4 \%) & 1(1.4 \%) \\ 1(1 \%) & 0(0 \%) \\ 1(1 \%) & 0(0 \%) \\ 2(2 \%) & 0(0 \%) \\ 1(1 \%) & 0(0 \%) \\ 1(1 \%) & 0(0 \%) \\ 1(1 \%) & 0(0 \%) \\ 5(5 \%) & 0(0 \%) \\ 2(2 \%) & 2(2.7 \%) \\ 0(0 \%) & 1(1.4 \%) \\ 11(11 \%) & 8(10.8 \%)\end{array}$

- Diabetes mellitus

- CML 


\section{Features}

Consolidation

Cavity

Nodules

Ground glass opacities

Pleural effusion

Pleural thickening

Bronchiectasis
Non-CPA $(n=100)$

$33(39.8 \%)$

$22(29.3 \%)$

$40(49.4 \%)$

$22(30.1 \%)$

$16(22.2 \%)$

$10(10.3 \%)$

$36(36 \%)$
CPA $(n=74)$

P-value

$35(48.6 \%) \quad 0.33$

$61(85.9 \%) \quad<0.001$

$42(61.8 \%) \quad 0.14$

$26(41.3 \%) \quad 0.21$

$5(8.8 \%) \quad 0.06$

$24(32.9 \%) \quad<0.001$

$46(62.2 \%)$

0.001




\begin{tabular}{|c|c|c|c|}
\hline Variables & Non-CPA ( $n=100)$ & CPA $(n=74)$ & P-value \\
\hline $\begin{array}{l}\text { LDBio LFA positive } \\
\text { Weakly positive }\end{array}$ & $\begin{array}{l}19(19 \%) \\
2(2 \%)\end{array}$ & $\begin{array}{l}50(67.6 \%) \\
1(1.4 \%)\end{array}$ & $\begin{array}{l}<0.001 \\
0.6\end{array}$ \\
\hline Specific IgE (IQR) & $0.11(0.02-0.37)$ & $0.34(0.04-1.5)$ & 0.2 \\
\hline Total IgE (IQR) & $328(66.9-1465)$ & 406 (119-1035) & 0.8 \\
\hline Specific IgG (IQR) & $11.5(6.40-20.1)$ & $53.85(30-91)$ & $<0.001$ \\
\hline AEC (IQR) & $162.07(49.6-341.66)$ & $162.32(15.19-371.46)$ & 0.93 \\
\hline Specific lgE ( $\geq 0.1 \mathrm{KVA} / \mathrm{L})$ & $16 \quad(16 / 28,57.1 \%)$ & $30 \quad(30 / 46,65.2 \%)$ & 0.49 \\
\hline Total lgE ( $\geq 500$ KVA/L) & $14 \quad(14 / 31,45.2 \%)$ & $20 \quad(20 / 47,42.6 \%)$ & 0.82 \\
\hline Specific lgG ( $\geq 27 \mathrm{MgA} / \mathrm{L})$ & $18 \quad(18.0 \%)$ & $61 \quad(82.4 \%)$ & $<0.001$ \\
\hline $\mathrm{AEC}(\geq 500$ cells $/ \mathrm{mm} 3)$ & $13 \quad(13 / 60,21.7 \%)$ & $10 \quad(10 / 50,20 \%)$ & 0.83 \\
\hline Positive direct $\mathrm{KOH}$ & $4 \quad(4 / 55,7.8 \%)$ & $\begin{array}{ll}6 & (6 / 53,11.3 \%) \\
\end{array}$ & 0.52 \\
\hline $\begin{array}{l}\text { Positive fungal culture } \\
\text { Aspergillus fumigatus } \\
\text { Aspergillus flavus } \\
\text { Aspergillus niger } \\
\text { Aspergillus spp. }\end{array}$ & $\begin{array}{ll}2 & (2 / 70,2.9 \%) \\
2^{*} & \\
1^{*} & \end{array}$ & $\begin{array}{ll}7 & (7 / 61,11.5 \%) \\
2 & \\
3 & \\
1 & \\
1 & \\
\end{array}$ & 0.08 \\
\hline $\begin{array}{l}\text { Serum galactomannan } \\
(\geq 1.0)\end{array}$ & $10 \quad(10 / 28,35.7 \%)$ & $16 \quad(16 / 39,41 \%)$ & 0.66 \\
\hline BAL galactomannan $(\geq 1.0)$ & $(7 / 30,23.3 \%)$ & $(17 / 28,60.7 \%)$ & 0.004 \\
\hline ZN AFB +ve & $2 \quad(2 / 48,4.2 \%)$ & $(0 / 41,0 \%)$ & 0.49 \\
\hline MGIT +ve & $(5 / 30,16.7 \%)$ & $(0 / 25,0 \%)$ & 0.06 \\
\hline GeneXpert & $(9 / 55,16.4 \%)$ & $(4 / 54,7.4 \%)$ & 0.24 \\
\hline Any TB investigation +ve & $(12 / 100,12.0 \%)$ & $(4 / 74,5.4 \%)$ & 0.19 \\
\hline
\end{tabular}

*One patient showed mixed growth of Asperillus niger and Aspergillus flavus IQR: Interquartile range AEC: absolute eosinophil count ZN AFB: ZIEHL-NEELSEN acid-fast bacillus MGIT: Mycobacteria Growth Indicator Tube 
Sym ptoms $>4$ weeks

LDB io LFA

\section{(D)}

IgG Aspergillus

LD Bio -ve

Non-CPA

\begin{tabular}{l|l} 
CPA & $67.6 \%$
\end{tabular}

fumigatus

LD Bio +ve

81

24

19

50

(55.7\%-

$78 \%)$

Non-CPA

CPA

$82.4 \%$

IgG -ve

82

13

$171.8 \%$ -

18

61

$90.3 \%$ )

\begin{tabular}{|l|}
$81 \%$ \\
$(71.9 \%-$ \\
$81 \%)$ \\
$82 \%$ \\
$(73.1 \%-$ \\
$89 \%)$ \\
\hline
\end{tabular}

Sym ptom s $>4$ weeks and prior history of PTB

LDB io LFA

\begin{tabular}{l} 
\\
\hline IgG Aspergillus \\
fumigatus
\end{tabular}

fumigatus
LD Bio -ve

LDBio +ve

Non-CPA

47

Ig $G-v e$

$\lg G+v e$

11

9
Non-CPA
45

CPA
16
44
CPA
8
52

Sym ptom $s>3$ months $w$ ith past history of tuberculosis

LDB io LFA

\begin{tabular}{l} 
\\
\hline IgG Aspergillus \\
fum igatus
\end{tabular}

LD B io -ve

$L D B$ io +ve

Non-CPA

34

$\begin{array}{lr}\text { Nong-ve } & 33 \\ \text { IgG +ve } & 7\end{array}$

6

7

Non-CPA

46

\begin{tabular}{c|l} 
CPA & $74.1 \%$ \\
14 & $(60.3 \%$ \\
40 & $85 \%)$ \\
\hline CPA & $85.2 \%$ \\
8 & $(72.9 \%$ \\
46 & $93.4 \%$
\end{tabular}

Sym ptoms $>4$ w eeks $w$ ith lung cavity

\begin{tabular}{|l|lcc|l|}
\hline LDB io LFA & & Non-CPA & CPA & $68.9 \%$ \\
& LDBio -ve & 18 & 19 & $(55.7 \%-$ \\
& LDBio +ve & 4 & 42 & $80.1 \%)$ \\
\hline IgG Aspergillus & & Non-CPA & CPA & $82 \%$ \\
fumigatus & IgG -ve & 19 & 11 & $(70 \%-$ \\
& IgG +ve & 3 & 50 & $90.6 \%)$
\end{tabular}

Sym ptoms $>4$ w eeks excluding abpa

LDB io LFA
IgG Aspergillus
fumigatus

\begin{tabular}{lcc|l} 
& Non-CPA & CPA & $67.12 \%$ \\
LDBio -ve & 79 & 24 & $(55.1 \%$ \\
LDBio +ve & 9 & 49 & $77.7 \%)$ \\
& Non-CPA & CPA & $82.19 \%$ \\
IgG -ve & 77 & 13 & $(71.5 \%$ \\
IgG + ve & 11 & 60 & $90.2 \%)$
\end{tabular}

Sym ptoms $>4$ weeks with bronchiectasis and excluding abpa

LDB io LFA

lgG Aspergillus fumigatus

\begin{tabular}{|l|}
\hline $80 \%$ \\
$(65.4 \%-$ \\
$90.4 \%)$ \\
$86.7 \%$ \\
$(73.2 \%-$ \\
$95 \%)$
\end{tabular}

$\begin{array}{lcc} & \text { Non-CPA } & \text { CPA } \\ \text { LD B io -ve } & 26 & 9 \\ \text { LDB io +ve } & 4 & 36 \\ & \text { Non-CPA } & \text { CPA } \\ \lg \text {-ve } & 26 & 6 \\ \lg G+v e & 4 & 39\end{array}$

$83.9 \%$

$(71.7 \%$ -

$92.4 \%$ )

$80.4 \%$

$167.6 \%$ -

$89.8 \%$

1

\begin{tabular}{|ll|}
$85 \%$ & $78.7 \%$ \\
$(70.2 \%-$ & $(69.1 \%-$ \\
$94.3 \%)$ & $86.5 \%)$ \\
\hline $82.5 \%$ & $84 \%$ \\
$(67.2 \%-$ & $(75.1 \%-$ \\
$92.7 \%)$ & $90.8 \%)$
\end{tabular}

$78.5 \%$

(69.9\% $85.5 \%)$

$83.6 \%$
$175.6 \%$ -

$89.8 \%)$

$68.19 \%$ -

$82.2 \%$

$175.68 \%$ -

$87.56 \%$ )

\begin{tabular}{|ll|}
\hline $81.82 \%$ & $72.3 \%$ \\
$(59.7 \%-$ & $(61.4 \%-$ \\
$94.8 \%)$ & $81.6 \%)$ \\
\hline $86.4 \%$ & $83.1 \%$ \\
$(65.1 \%-$ & $(73.3 \%-$ \\
$97.1 \%)$ & $90.5 \%)$
\end{tabular}

$79.5 \%$
$(72.4 \%$
$85.5 \%)$
$85.1 \%$
$(78.6 \%$
$90.2 \%)$

$\begin{array}{ll}89.77 \% & 79.5 \% \\ (81.5 \%- & (72.4 \%- \\ 95.2 \%) & 85.5 \%) \\ 87.50 \% & 85.1 \% \\ (78.7 \%- & (78.6 \%- \\ 93.4 \%) & 90.2 \%)\end{array}$

\begin{tabular}{|l|}
\hline $86.67 \%$ \\
$(69.28 \%$ \\
$96.2 \%)$ \\
$86.7 \%$ \\
$(69.3 \%-$ \\
$96.2 \%)$ \\
\hline
\end{tabular}

$82.7 \%$
$(72.2 \%-$
$90.4 \%)$
$86.7 \%$
$(76.8 \%-93.4 \%)$

$82.7 \%$ $90.4 \%$ )

$86.7 \%$

(76.8\%-93.4\%) 
Diagnostic accuracy

Symptom $s>4$ weeks

$$
\text { LDB io LFA }
$$

\begin{tabular}{|c|c|c|c|c|c|c|}
\hline LD B io LFA & $\begin{array}{l}\text { LDB io -ve } \\
\text { LDB io +ve }\end{array}$ & $\begin{array}{c}\text { Non-CPA } \\
86 \\
28 \\
\end{array}$ & $\begin{array}{l}\text { CPA } \\
19 \\
41 \\
\end{array}$ & $\begin{array}{l}68.3 \% \\
155.04 \%- \\
79.74 \%\end{array}$ & $\begin{array}{l}75.4 \% \\
166.49 \%- \\
83.02 \%\end{array}$ & $\begin{array}{l}72.99 \% \\
(65.75 \%-79.43 \%)\end{array}$ \\
\hline IgG Aspergillus & & Non-CPA & CPA & $75 \%$ & $90.35 \%$ & $85.06 \%$ \\
\hline fum igatus & $\begin{array}{l}\lg G-v e \\
\lg G+v e\end{array}$ & $\begin{array}{l}103 \\
11 \\
\end{array}$ & $\begin{array}{l}15 \\
45 \\
\end{array}$ & $\begin{array}{l}(62.14 \% \\
85.28 \%) \\
\end{array}$ & $\begin{array}{l}(83.39 \%- \\
95.08 \%)\end{array}$ & $(78.88 \%-90.00 \%)$ \\
\hline \multicolumn{7}{|c|}{ Symptom $s>4$ w eeks and prior history of PTB } \\
\hline LDB io LFA & $\begin{array}{l}L D B \text { io -ve } \\
L D B \text { io + ve }\end{array}$ & $\begin{array}{c}\text { Non-CPA } \\
51 \\
16\end{array}$ & $\begin{array}{l}C P A \\
12 \\
37\end{array}$ & $\begin{array}{l}75.51 \% \\
(61.13 \% \\
86.66 \%)\end{array}$ & $\begin{array}{l}76.12 \% \\
164.14 \% \\
85.69 \%\end{array}$ & $\begin{array}{l}75.86 \% \\
(67.04 \%-83.32 \%)\end{array}$ \\
\hline $\begin{array}{l}\text { Ig G Aspergillus } \\
\text { fum igatus }\end{array}$ & $\begin{array}{l}\lg G-v e \\
\lg G+v e\end{array}$ & $\begin{array}{l}\text { Non-CPA } \\
61 \\
6\end{array}$ & $\begin{array}{l}\text { CPA } \\
10 \\
39\end{array}$ & $\begin{array}{l}79.59 \% \\
(65.66 \% \\
89.76 \%)\end{array}$ & $\begin{array}{l}91.04 \% \\
(81.52 \% \\
96.64 \%)\end{array}$ & $\begin{array}{l}86.21 \% \\
178.57 \%-91.91 \%\end{array}$ \\
\hline \multicolumn{7}{|c|}{ Symptoms $>3 \mathrm{~m}$ onths $w$ ith past history of tuberculosis } \\
\hline LDB io LFA & $\begin{array}{l}\text { LDB io -ve } \\
\text { LDB io +ve }\end{array}$ & $\begin{array}{c}\text { Non-CPA } \\
37 \\
13\end{array}$ & $\begin{array}{l}C P A \\
11 \\
33\end{array}$ & $\begin{array}{l}75.00 \% \\
(59.66 \% \\
86.81 \%)\end{array}$ & $\begin{array}{l}74.00 \% \\
(59.66 \%- \\
85.37 \%)\end{array}$ & $\begin{array}{l}74.47 \% \\
(64.43 \%-82.91 \%)\end{array}$ \\
\hline $\begin{array}{l}\text { IgG Aspergillus } \\
\text { fum igatus }\end{array}$ & $\begin{array}{l}\lg G-v e \\
\lg G+v e\end{array}$ & $\begin{array}{l}\text { Non-CPA } \\
47 \\
3 \\
\end{array}$ & $\begin{array}{c}\text { CPA } \\
10 \\
34 \\
\end{array}$ & $\begin{array}{l}77.27 \% \\
(62.16 \%- \\
88.53 \%) \\
\end{array}$ & $\begin{array}{l}94.00 \% \\
183.45 \%- \\
98.75 \% \\
\end{array}$ & $\begin{array}{l}86.17 \% \\
(77.51 \%-92.43 \%)\end{array}$ \\
\hline LDB io LFA & & Non-CPA & CPA & $69.23 \%$ & $67.74 \%$ & $68.67 \%$ \\
\hline & $\begin{array}{l}\text { LDB io -ve } \\
\text { LDB io +ve }\end{array}$ & $\begin{array}{l}21 \\
10 \\
\end{array}$ & $\begin{array}{c}16 \\
36 \\
\end{array}$ & $\begin{array}{l}154.90 \%- \\
81.28 \%\end{array}$ & $\begin{array}{l}(48.63 \%- \\
83.32 \%)\end{array}$ & $(57.56 \%-78.41 \%)$ \\
\hline IgG Aspergillus & & Non-CPA & CPA & $76.92 \%$ & $96.77 \%$ & $84.34 \%$ \\
\hline fumigatus & $\begin{array}{l}\lg G-v e \\
\lg G+v e\end{array}$ & $\begin{array}{c}30 \\
1 \\
\end{array}$ & $\begin{array}{l}12 \\
40 \\
\end{array}$ & $\begin{array}{l}(63.16 \%- \\
87.47 \%) \\
\end{array}$ & $\begin{array}{l}(83.30 \%- \\
99.92 \%)\end{array}$ & $(74.71 \%-91.39 \%)$ \\
\hline \multicolumn{7}{|c|}{ Symptoms $>4$ w eeks excluding abpa } \\
\hline LDB io LFA & & Non-CPA & CPA & $67.80 \%$ & $82.35 \%$ & $77.02 \%$ \\
\hline & $\begin{array}{l}\text { LDB io -ve } \\
\text { LDB io +ve }\end{array}$ & $\begin{array}{l}84 \\
18\end{array}$ & $\begin{array}{c}19 \\
40\end{array}$ & $\begin{array}{l}(54.36 \%- \\
79.38 \%)\end{array}$ & $\begin{array}{l}(73.55 \%- \\
89.19 \%)\end{array}$ & $(69.74 \%-83.27 \%)$ \\
\hline IgG Aspergillus & & Non-CPA & CPA & $76.27 \%$ & $95.10 \%$ & $88.20 \%$ \\
\hline fum igatus & $\begin{array}{l}\lg G-v e \\
\lg G+v e\end{array}$ & $\begin{array}{l}97 \\
5\end{array}$ & $\begin{array}{r}14 \\
45\end{array}$ & $\begin{array}{l}(63.41 \% \\
86.38 \%)\end{array}$ & $\begin{array}{l}(88.93 \% \\
98.39 \%)\end{array}$ & $(82.19 \%-92.74 \%)$ \\
\hline \multicolumn{7}{|c|}{ Symptoms $>4$ weeks with bronchiectasis and excluding abpa } \\
\hline LDB io LFA & $\begin{array}{l}\text { LDB io -ve } \\
\text { LDB io +ve }\end{array}$ & $\begin{array}{c}\text { Non-CPA } \\
28 \\
11 \\
\end{array}$ & $\begin{array}{l}\text { CPA } \\
7 \\
29 \\
\end{array}$ & $\begin{array}{l}80.56 \% \\
(63.98 \% \\
91.81 \%)\end{array}$ & $\begin{array}{l}71.79 \% \\
(55.13 \%- \\
85.00 \%)\end{array}$ & $\begin{array}{l}76.00 \% \\
(64.75 \%-85.11 \%)\end{array}$ \\
\hline $\begin{array}{l}\text { Ig A Aspergillus } \\
\text { fum igatus }\end{array}$ & $\begin{array}{l}\lg G-v e \\
\lg G+v e\end{array}$ & $\begin{array}{l}\text { N on }-\mathrm{CPA} \\
37 \\
2 \\
\end{array}$ & $\begin{array}{r}\text { CPA } \\
7 \\
29 \\
\end{array}$ & $\begin{array}{l}80.56 \% \\
(63.98 \% \\
91.81 \%) \\
\end{array}$ & $\begin{array}{l}94.87 \% \\
(82.68 \%- \\
99.37 \%) \\
\end{array}$ & $\begin{array}{l}88.00 \% \\
(78.44 \%-94.36 \%)\end{array}$ \\
\hline
\end{tabular}

Symptom $s>3$ months w ith past history of tuberculosis 


\begin{tabular}{|c|c|c|c|c|c|c|c|}
\hline Author & Country/Year & Study type & Population & Comparator & $\begin{array}{l}\text { Sensiti } \\
\text { vity }\end{array}$ & $\begin{array}{l}\text { Specifi } \\
\text { city }\end{array}$ & Others \\
\hline $\begin{array}{l}\text { Piarroux } \\
\text { et al }{ }^{16}\end{array}$ & France/2019 & $\begin{array}{l}\text { Both } \\
\text { retrospective } \\
\text { and } \\
\text { prospective }\end{array}$ & $\begin{array}{l}\text { All samples } \\
\text { received for } \\
\text { Aspergillus } \\
\text { serology(ABPA, } \\
\text { CPA, IA SAIA*). } \\
\text { Retrospective: } \\
262 \text { cases ( } 68 \\
\text { CPA) \& } 188 \\
\text { controls. } \\
\text { Prospective: } \\
44 \text { cases (11 } \\
\text { CPA) \& } 213 \\
\text { non-cases }\end{array}$ & $\begin{array}{l}\text { Who did not } \\
\text { correspond to } \\
\text { case definition } \\
\text { of CPA }\end{array}$ & $88.9 \%$ & $96.3 \%$ & $\begin{array}{l}\text { Definition of } \\
\text { CPA as per } \\
\text { ERS/ESCMID }\end{array}$ \\
\hline $\begin{array}{l}\text { Hunter et } \\
\mathrm{al}^{17}\end{array}$ & UK/ 2019 & $\begin{array}{l}\text { Cross } \\
\text { sectional }\end{array}$ & $\begin{array}{l}\text { CPA patient } \\
\text { sera. } 154 \text { CPA } \\
\text { patients, } 150 \\
\text { healthy } \\
\text { controls. }\end{array}$ & $\begin{array}{l}\text { Healthy } \\
\text { control }\end{array}$ & $91.6 \%$ & $98 \%$ & $\begin{array}{l}\text { Definition of } \\
\text { CPA as per } \\
\text { ERS/ESCMID }\end{array}$ \\
\hline $\begin{array}{l}\text { Rozaliyani } \\
\text { et } \text { al }^{22}\end{array}$ & $\begin{array}{l}\text { Indonesia/ } \\
2020\end{array}$ & $\begin{array}{l}\text { ? } \\
\text { Prospective }\end{array}$ & $\begin{array}{l}\text { Adults with } \\
\text { symptoms } \\
\text { after } \\
\text { completing } \\
\text { tuberculosis } \\
\text { therapy. }\end{array}$ & $\begin{array}{l}\text { Patients } \\
\text { without } \\
\text { diagnosis CPA }\end{array}$ & $80 \%$ & $70 \%$ & $\begin{array}{l}\text { Sputum for } \\
\text { fungal } \\
\text { culture was } \\
\text { used as an } \\
\text { essential } \\
\text { diagnostic } \\
\text { criterion. }\end{array}$ \\
\hline $\begin{array}{l}\text { Ray et al } \\
\text { (present } \\
\text { study) }\end{array}$ & $\begin{array}{l}\text { India/ 2021- } \\
22 \text { present } \\
\text { study }\end{array}$ & Prospective & $\begin{array}{l}\text { Patients } \\
\text { presenting } \\
\text { with } \\
\text { respiratory } \\
\text { symptoms > } 4 \\
\text { weeks. } 74 \text { CPA } \\
\& 100 \text { non-CPA } \\
\text { patients }\end{array}$ & $\begin{array}{l}\text { Patients being } \\
\text { tested who } \\
\text { did not have } \\
\text { CPA }\end{array}$ & $67.6 \%$ & $81 \%$ & $\begin{array}{l}\text { Definition of } \\
\text { CPA as per } \\
\text { ERS/ESCMID }\end{array}$ \\
\hline & & & & & & & \\
\hline
\end{tabular}

